\title{
Enhancing the Photovoltaic Performance and Moisture Stability of Perovskite Solar Cells via Polyfluoroalkylated Imidazolium Additives
}

\author{
Xiangdong Li', Changzhi L ${ }^{2}$, Xin Zhao ${ }^{3}$, Yuqing Zhang', Ganghong Liu', \\ Zehao Zhang1, Duo Wang', Lixin Xiao', Zhijian Chen ${ }^{1}$, and Bo Qu ${ }^{1, *}$
}

${ }^{1}$ State Key Laboratory for Artificial Microstructures and Mesoscopic Physics, Department of Physics, Peking University, Beijing 100871, P. R. China

${ }^{2}$ State Key Laboratory of Silicon Materials, MOE Key Laboratory of Macromolecular Synthesis and Functionalization, Department of Polymer Science and Engineering, Zhejiang University, Hangzhou 310027, P. R. China ${ }^{3}$ Key Laboratory of Synthetic and Self-Assembly Chemistry for Organic Functional Molecules, Center for Excellence in Molecular Synthesis, Shanghai Institute of Organic Chemistry, Chinese Academy of Sciences, Shanghai 200032, P. R. China

Corresponding Author

bqu@pku.edu.cn (Bo Qu) 


\section{Synthesis and characterization of ion liquids}

MFIM-2. The experimental procedures for the preparation of this ion liquid is provided in the text. Colorless oil (53\%). ${ }^{1} \mathrm{H}$ NMR $\left(400 \mathrm{MHz}, \mathrm{DMSO}-\mathrm{d}_{6}\right): 9.14$ (s, 1H), $7.82(\mathrm{~d}, J=5.4 \mathrm{~Hz}, 1 \mathrm{H}), 7.68(\mathrm{~d}, J=5.4 \mathrm{~Hz}, 1 \mathrm{H}), 4.53-4.47(\mathrm{~m}, 2 \mathrm{H})$, $3.83(\mathrm{~s}, 3 \mathrm{H}), 2.98-2.86(\mathrm{~m}, 2 \mathrm{H}) \mathrm{ppm} .{ }^{13} \mathrm{C}$ NMR (100 MHz, DMSO): 137.5, 124.0, 122.9, 41.45, 36.14, $30.26\left(\mathrm{t}, J_{\mathrm{CF}}=20 \mathrm{~Hz}\right)$ ppm. ${ }^{19} \mathrm{~F}$ NMR $(376 \mathrm{MHz}$, DMSO$\left.\mathrm{d}_{6}\right):-84.86\left(\mathrm{~s}, 3 \mathrm{~F}, \mathrm{CF}_{3}\right),-116.97\left(\mathrm{~s}, 2 \mathrm{~F}, \mathrm{CF}_{2}\right),-148.20\left(\mathrm{~s}, 4 \mathrm{~F}, \mathrm{BF}_{4}\right) \mathrm{ppm} . \mathrm{HRMS}$

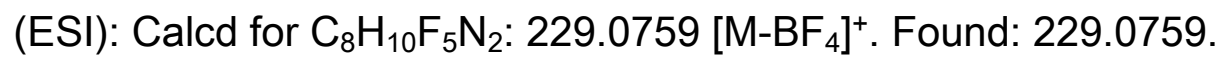

MFIM-4 and MFIM-6 were prepared from the reaction of 1-methylimidazole with $1,1,1,2,2,3,3,4,4$-nonafluoro-6-iodohexane or $1,1,1,2,2,3,3,4,4,5,5,6,6,-$ tridecafluoro-8-iodooctane according to the above procedure for MFIM-2. MFIM-4: Colorless oil (54\%). ${ }^{1} \mathrm{H}$ NMR (400 MHz, DMSO-d $\left.\mathrm{d}_{6}\right): 9.14$ (s, 1H), 7.82 $(\mathrm{d}, J=5.4 \mathrm{~Hz}, 1 \mathrm{H}), 7.67(\mathrm{~d}, J=5.4 \mathrm{~Hz}, 1 \mathrm{H}), 4.56-4.46(\mathrm{~m}, 2 \mathrm{H}), 3.82(\mathrm{~s}, 3 \mathrm{H})$, 3.04-2.87 (m, 2H) ppm. ${ }^{13} \mathrm{C}$ NMR (100 MHz, DMSO): 137.6, 124.0, 122.9, 41.50, 36.12, $29.97\left(\mathrm{t}, J_{\mathrm{CF}}=20 \mathrm{~Hz}\right)$ ppm. ${ }^{19} \mathrm{~F}$ NMR $\left(376 \mathrm{MHz}, \mathrm{DMSO}-\mathrm{d}_{6}\right):-80.42(\mathrm{~s}$, $\left.3 \mathrm{~F}, \mathrm{CF}_{3}\right),-113.44\left(\mathrm{~s}, 2 \mathrm{~F}, \mathrm{CF}_{2}\right),-124.01\left(\mathrm{~s}, 2 \mathrm{~F}, \mathrm{CF}_{2}\right),-125.64\left(\mathrm{~s}, 2 \mathrm{~F}, \mathrm{CF}_{2}\right)$, $-148.31\left(\mathrm{~s}, 4 \mathrm{~F}, \mathrm{BF}_{4}\right)$ ppm. HRMS (ESI): Calcd for $\mathrm{C}_{10} \mathrm{H}_{10} \mathrm{~F}_{9} \mathrm{~N}_{2}: 329.0695$ [M$\left.\mathrm{BF}_{4}\right]^{+}$. Found: 329.0694. MFIM-6: Colorless oil (65\%). ${ }^{1} \mathrm{H}$ NMR $(400 \mathrm{MHz}$, DMSO-d $\left.\mathrm{d}_{6}\right): 9.15(\mathrm{~s}, 1 \mathrm{H}), 7.82(\mathrm{~d}, J=5.4 \mathrm{~Hz}, 1 \mathrm{H}), 7.68(\mathrm{~d}, J=5.4 \mathrm{~Hz}, 1 \mathrm{H}), 4.55-$ $4.47(\mathrm{~m}, 2 \mathrm{H}), 3.83(\mathrm{~s}, 3 \mathrm{H}), 3.02-2.88(\mathrm{~m}, 2 \mathrm{H}) \mathrm{ppm} .{ }^{13} \mathrm{C} \mathrm{NMR}(100 \mathrm{MHz}, \mathrm{DMSO})$ : $137.5,124.0,122.8,41.52,36.13,29.97\left(\mathrm{t}, J_{\mathrm{CF}}=20 \mathrm{~Hz}\right) \mathrm{ppm} .{ }^{19} \mathrm{~F}$ NMR $(376$ $\left.\mathrm{MHz}, \mathrm{DMSO}-\mathrm{d}_{6}\right):-80.31\left(\mathrm{~s}, 3 \mathrm{~F}, \mathrm{CF}_{3}\right),-113.24\left(\mathrm{~s}, 2 \mathrm{~F}, \mathrm{CF}_{2}\right),-121.71(\mathrm{~s}, 2 \mathrm{~F}$, 
$\left.\mathrm{CF}_{2}\right),-122.67\left(\mathrm{~s}, 2 \mathrm{~F}, \mathrm{CF}_{2}\right),-123.23\left(\mathrm{~s}, 2 \mathrm{~F}, \mathrm{CF}_{2}\right),-125.82\left(\mathrm{~s}, 2 \mathrm{~F}, \mathrm{CF}_{2}\right),-148.25$ (s, 4F, BF $F_{4}$ ) ppm. HRMS (ESI): Calcd for $\mathrm{C}_{12} \mathrm{H}_{10} \mathrm{~F}_{13} \mathrm{~N}_{2}: 429.0631$ [M-BF $\left.\mathrm{B}_{4}\right]^{+}$. Found: 429.0632 .

Materials. $\mathrm{SnO}_{2}$ colloid precursor (tin (IV) oxide, $15 \%$ in $\mathrm{H}_{2} \mathrm{O}$ colloidal dispersion) and anhydrous DMSO and DMF were purchased from Alfa Aesar. $\mathrm{Pbl}_{2}$ (99.99\%) was purchased from Xi'an Polymer Light Technology Corporation. FAl and $\mathrm{MACl}(99.99 \%)$ were purchased from Borun New Materials. 2,2',7,7'-Tetrakis(N,N-di-pmethoxyphenylamine)-9,9'-spirobifluorene (Spiro-OMeTAD) was purchased from Fujian Wanrun New Energy Technology Co., Ltd. All these commercially available materials were used as received without any further purification.

Characterization. The XRD patterns were measured using X-ray diffraction system (PANalytical Inc.) with monochromatic Cu Ka irradiation $(\lambda=1.5418 \AA ̊)$. the SEM images were recorded using a high-resolution scanning electron microscopy (Hitachi S-4800). The steady-state photoluminescence (PL), excited at $470 \mathrm{~nm}$, was measured with NanoLog infrared fluorescence spectrometer (NanoLog L3-2lhr). The time resolved photoluminescence (TRPL) measurement was measured using UltraFast Lifetime Spectrometer (Delta flex). Photovoltaic performances were measured by using a Keithley 2611 source meter at AM $1.5 \mathrm{G}$ illumination $\left(100 \mathrm{mw} \mathrm{cm}^{-2}\right)$ under a Newport Thermal Oriel 69911300W solar simulator. The incident photon-to-current 
conversion efficiency (IPCE) spectrum was observed using a lock-in amplifier (model SR830 DSP) coupled with a 1/4m monochromator (Crowntech M24-s) and 150W tungsten lamp (Crowntech). All of the measurements of the solar cells were performed in an ambient atmosphere at room temperature without encapsulation. 


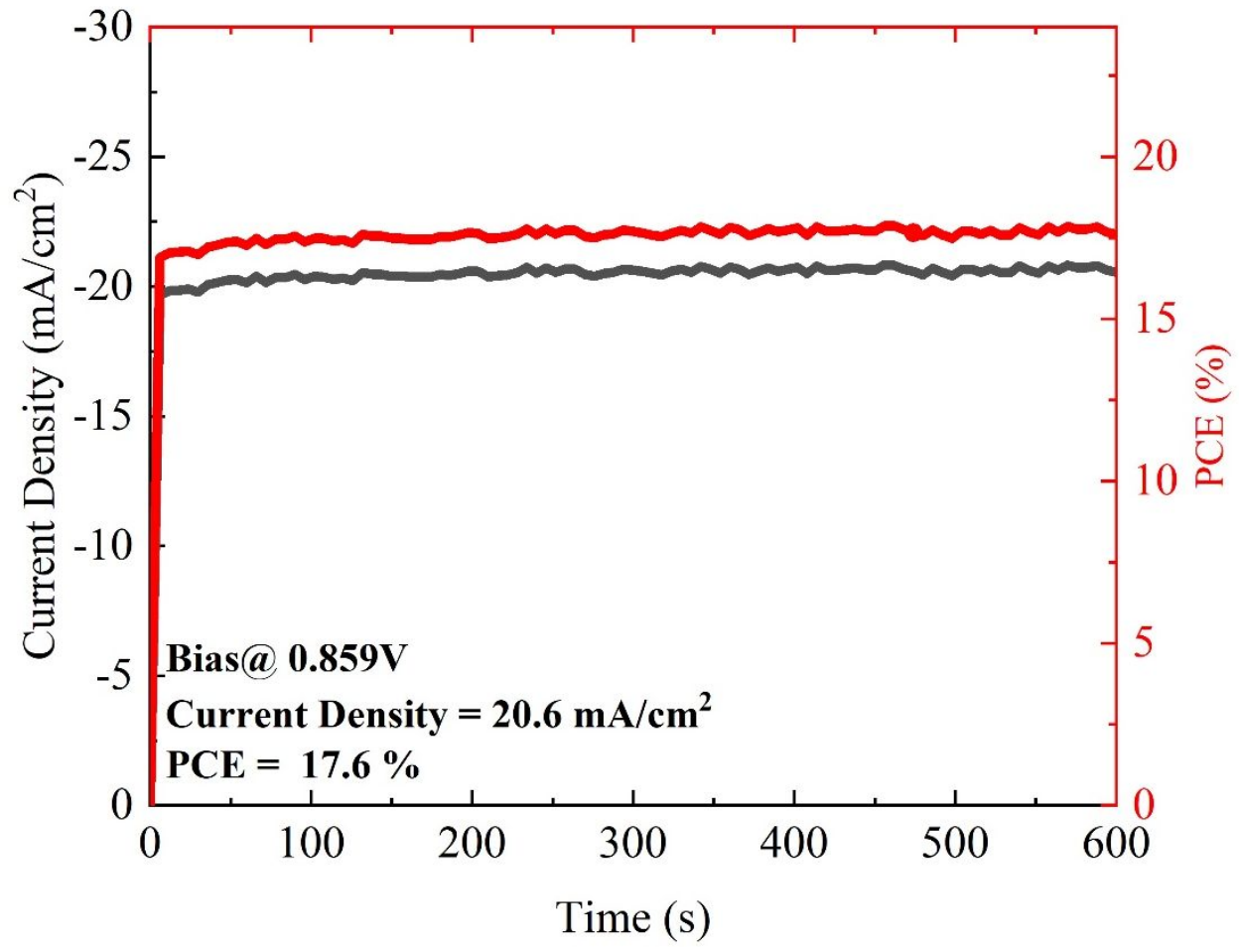

Figure S1. Steady-state current density and PCE as a function of time for the device with $0.5 \%$ MFIM-2.

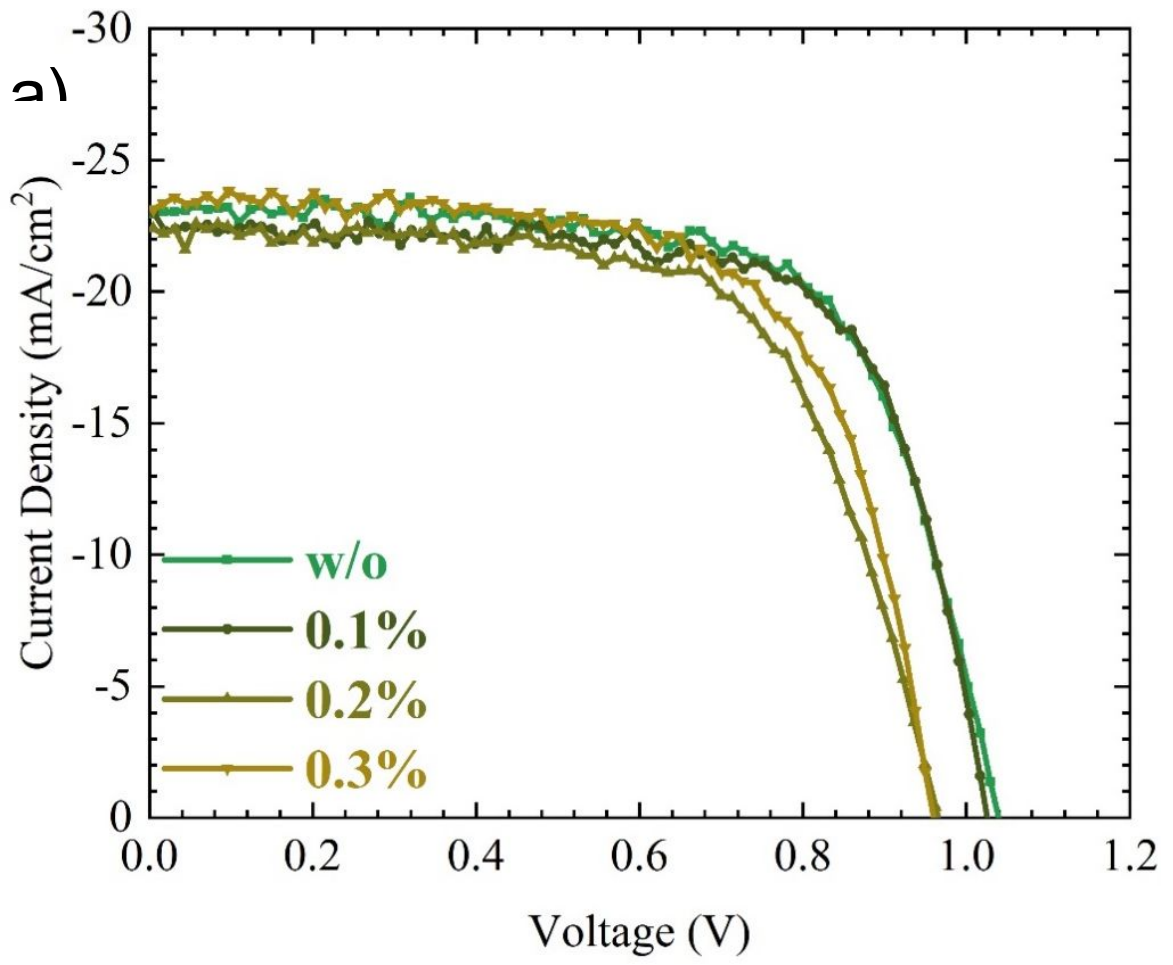




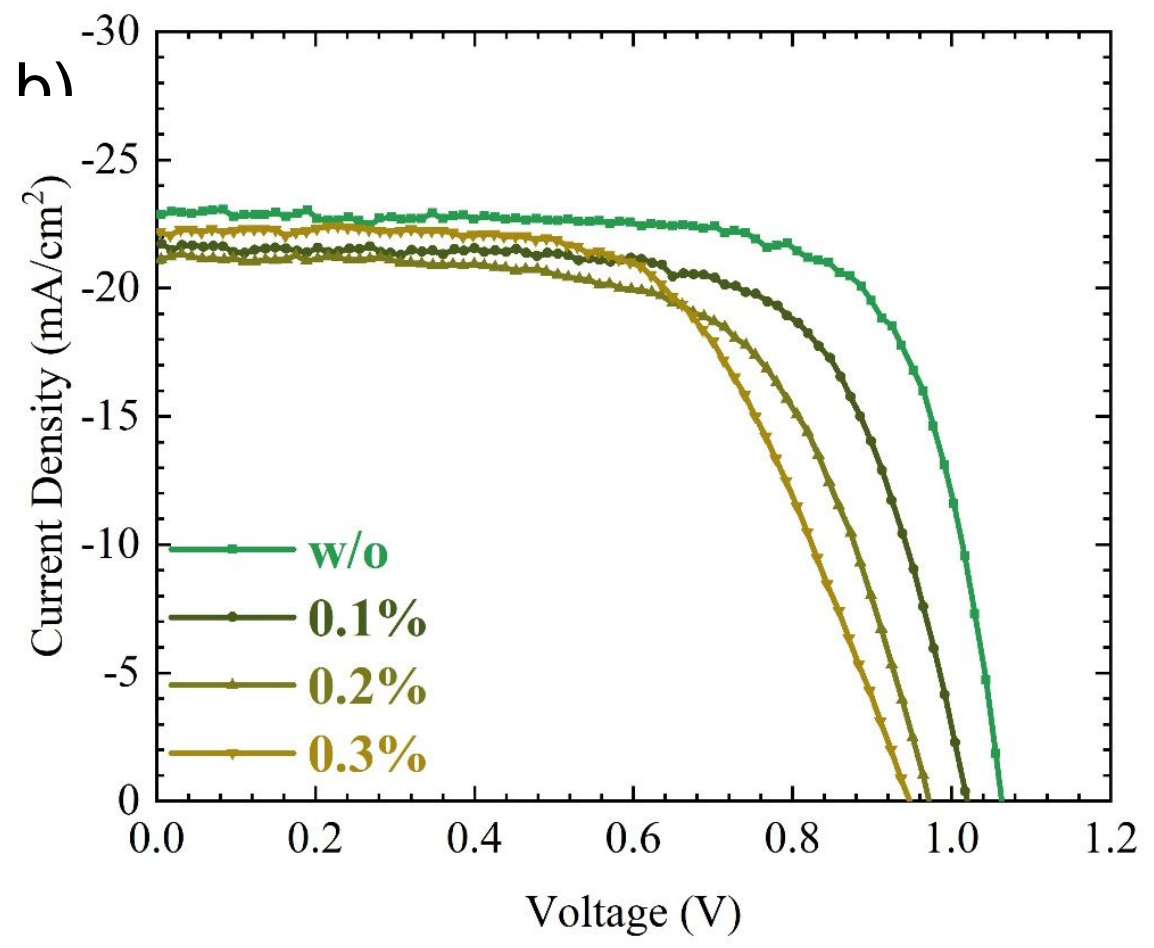

Figure S2. The J-V curves of the champion devices with different concentration of (a) MFIM-4 and (b) MFIM-6.

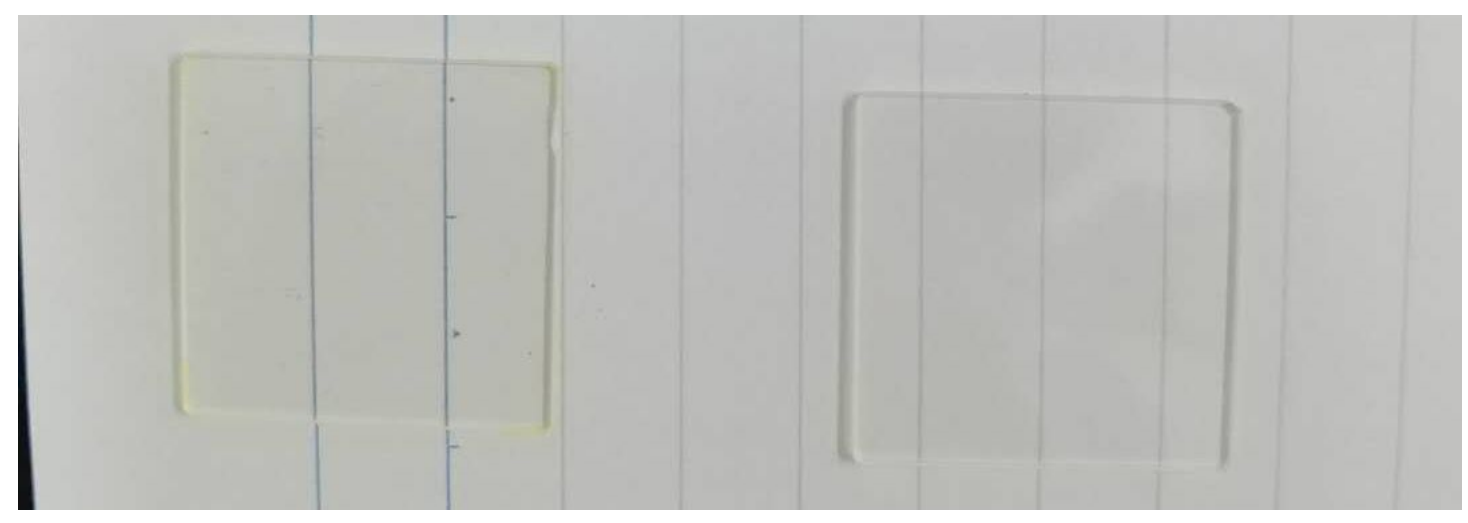

Figure S3. The photograph of $\mathrm{Pbl}_{2}$ (left) and $\mathrm{Pbl}_{2}+\mathrm{MFIM-2}$ (right) film. 


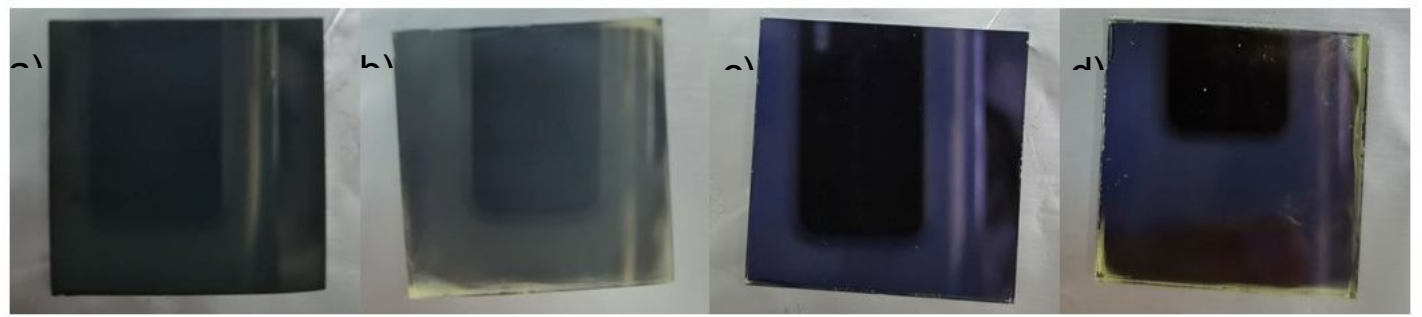

Figure S4. The photograph of perovskite film aged for 10 months. (a) Front, with MFIM-2. (b) Front, without MFIM-2. (c) Back, with MFIM-2. (d) Back, without MFIM-2.

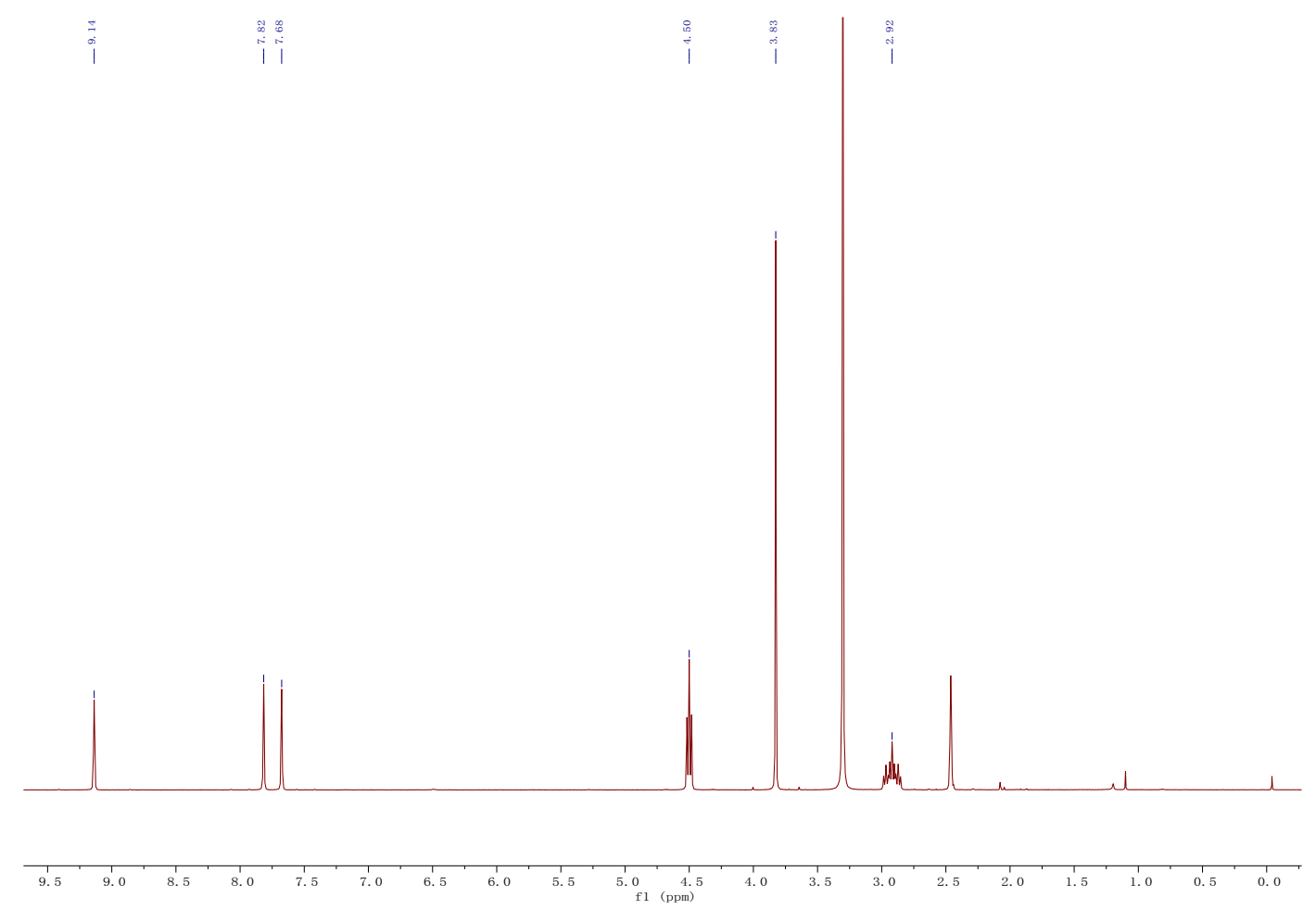

Figure S5. ${ }^{1} \mathrm{H}$ NMR (400 MHz) of MFIM-2 in DMSO-d 6 . 


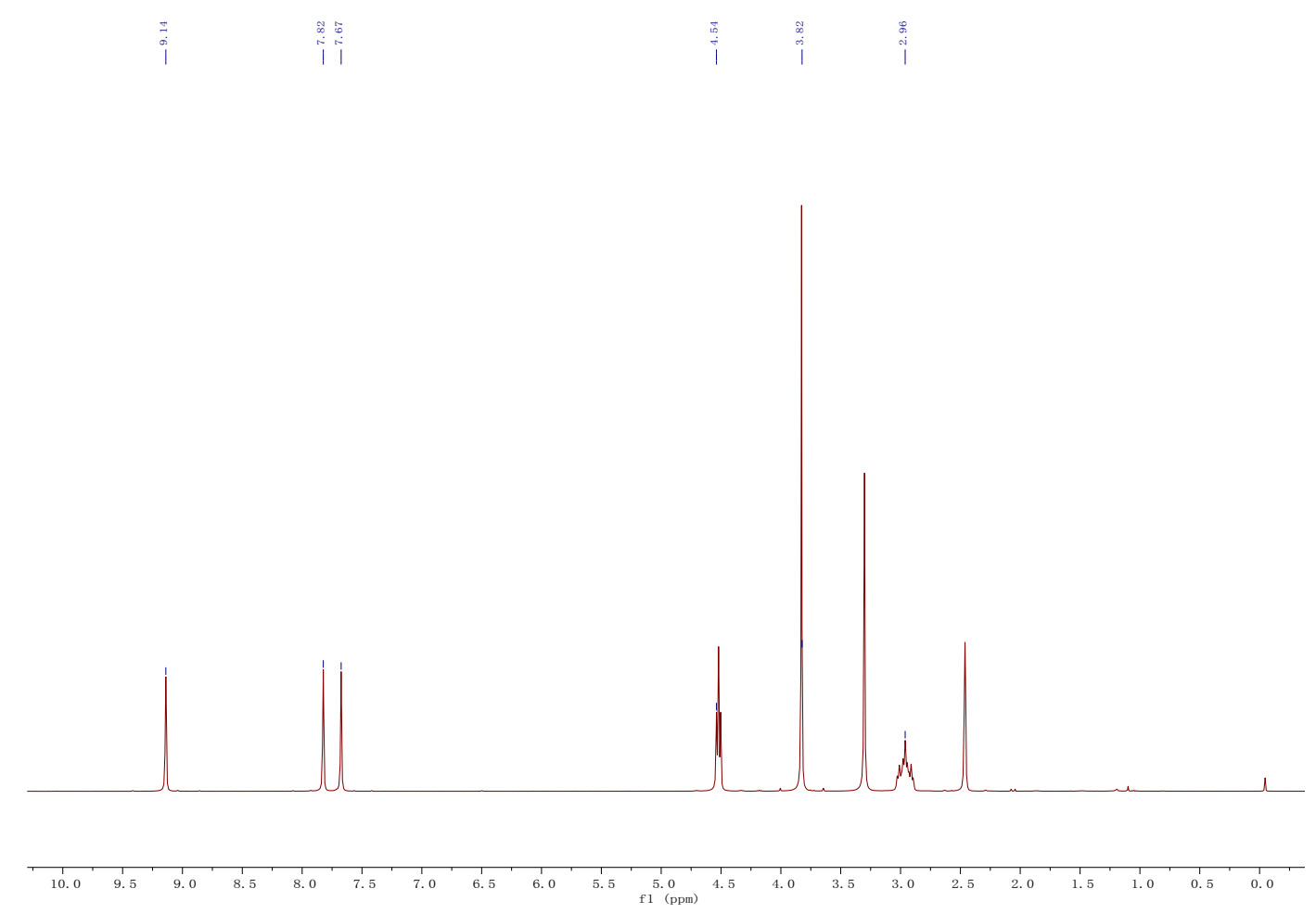

Figure S6. ${ }^{1} \mathrm{H}$ NMR $(400 \mathrm{MHz})$ of MFIM-4 in DMSO- $\mathrm{d}_{6}$.

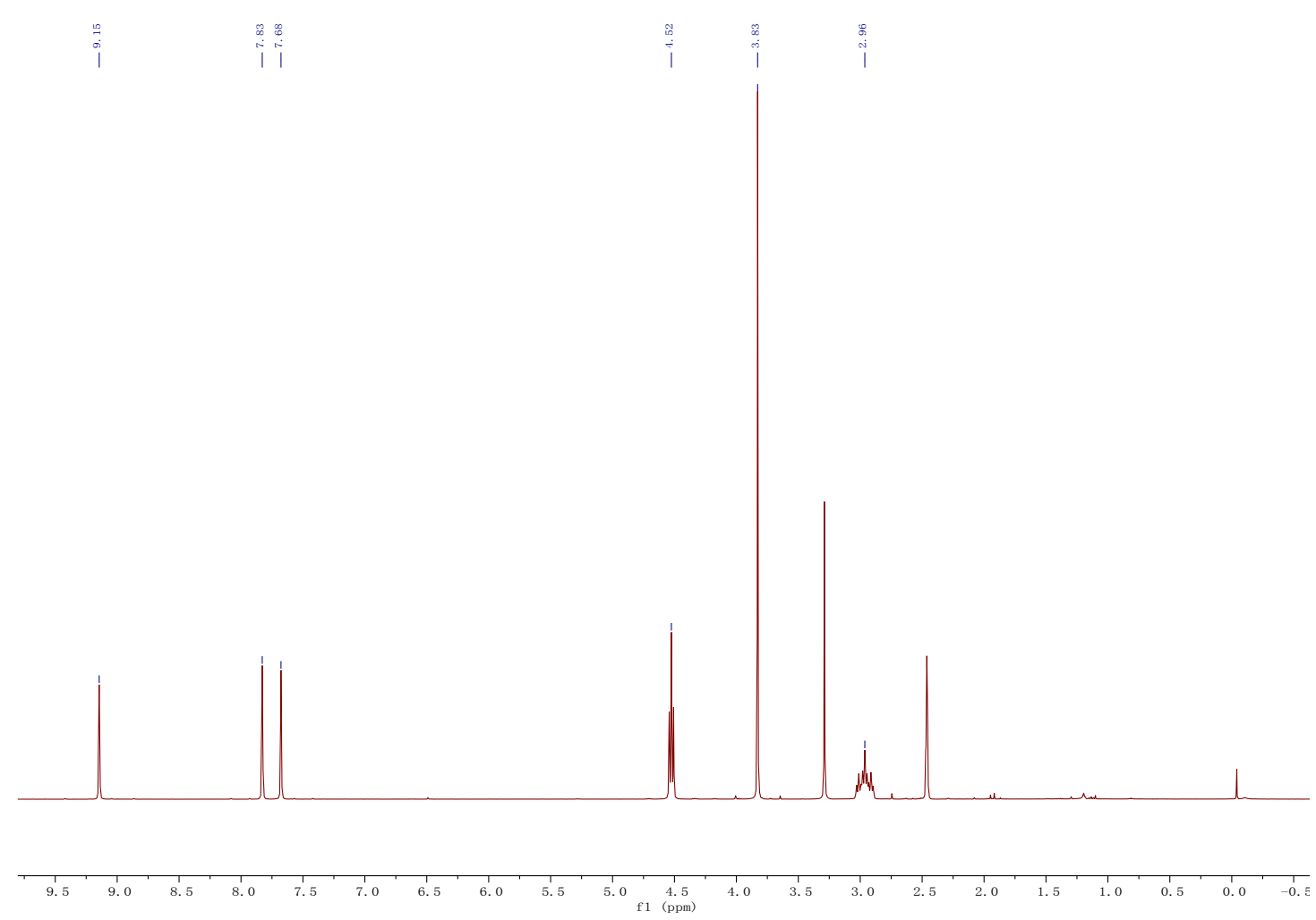


Figure S7. ${ }^{1} \mathrm{H}$ NMR $(400 \mathrm{MHz})$ of MFIM-6 in DMSO-d $\mathrm{d}_{6}$.

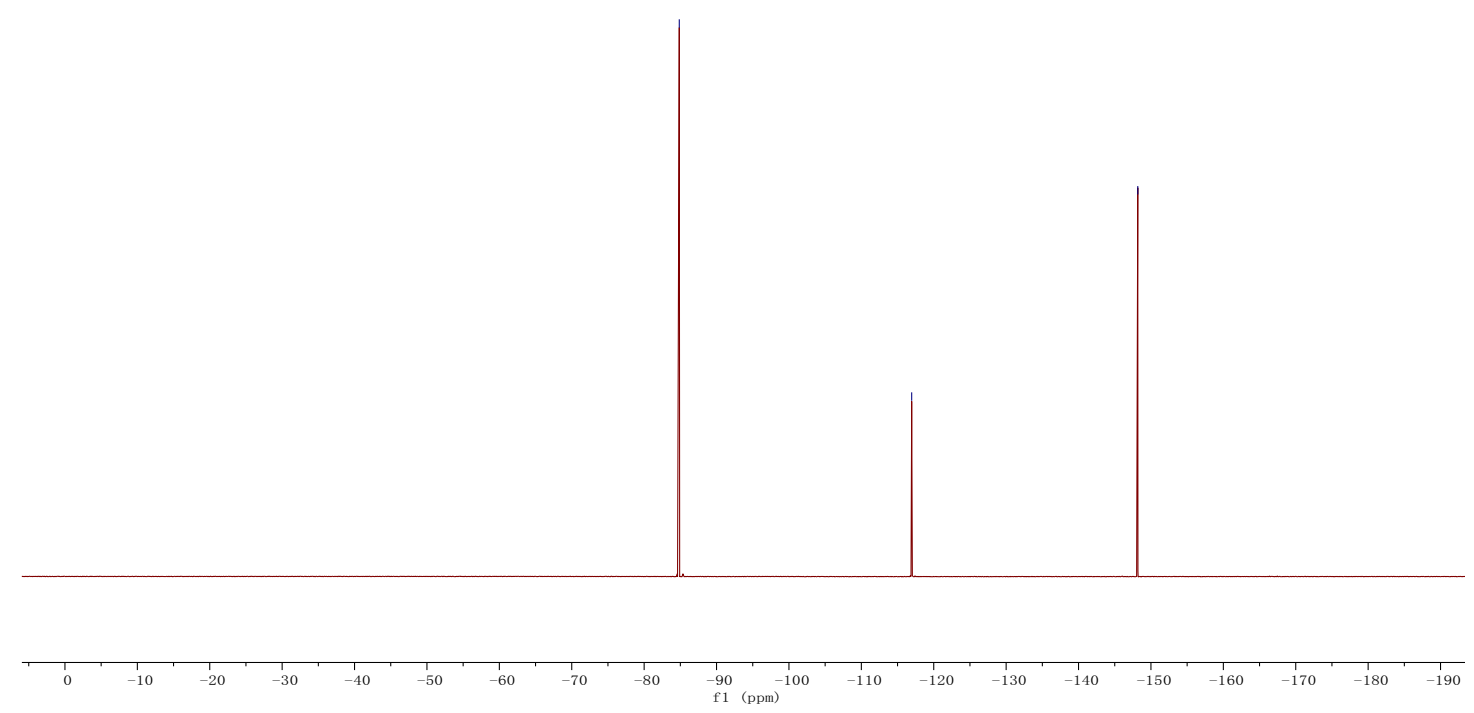

Figure S8. ${ }^{19} \mathrm{~F}$ NMR $(376 \mathrm{MHz})$ of MFIM-2 in DMSO-d 6 . 

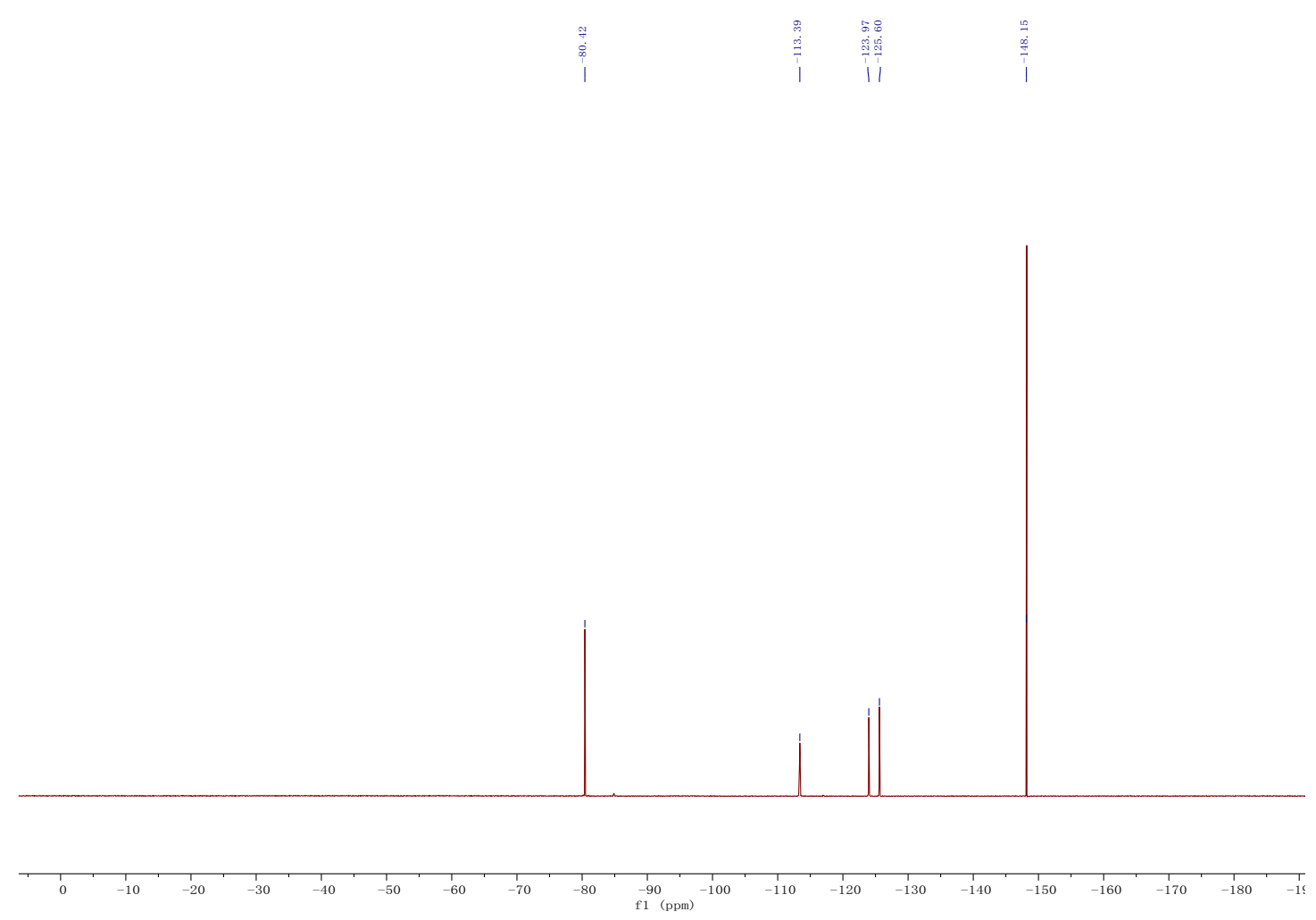

Figure S9. ${ }^{19} \mathrm{~F}$ NMR (376 MHz) of MFIM-4 in DMSO-d 6 .
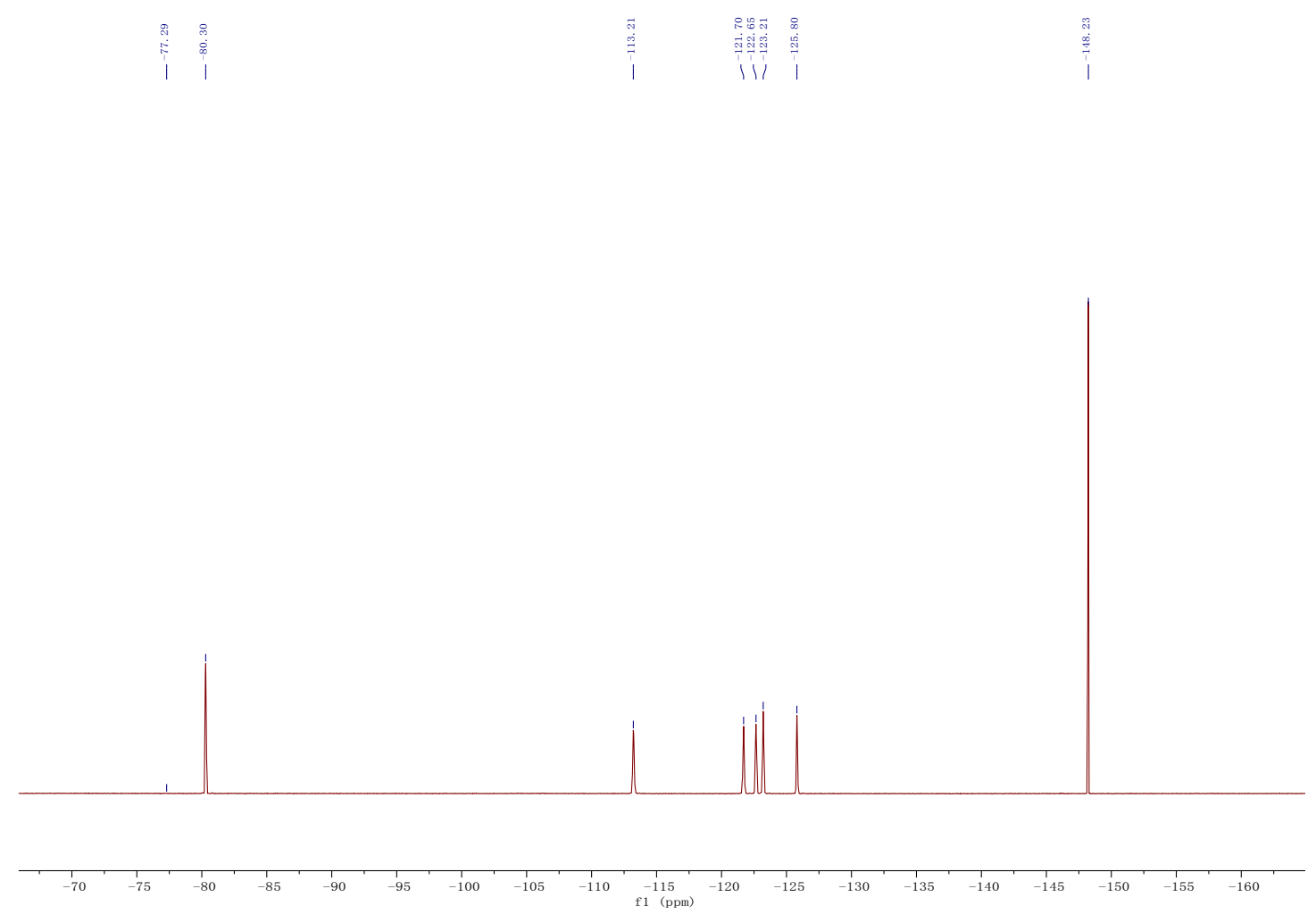

Figure S10. ${ }^{19} \mathrm{~F}$ NMR $(376 \mathrm{MHz})$ of MFIM-6 in DMSO-d 6 . 


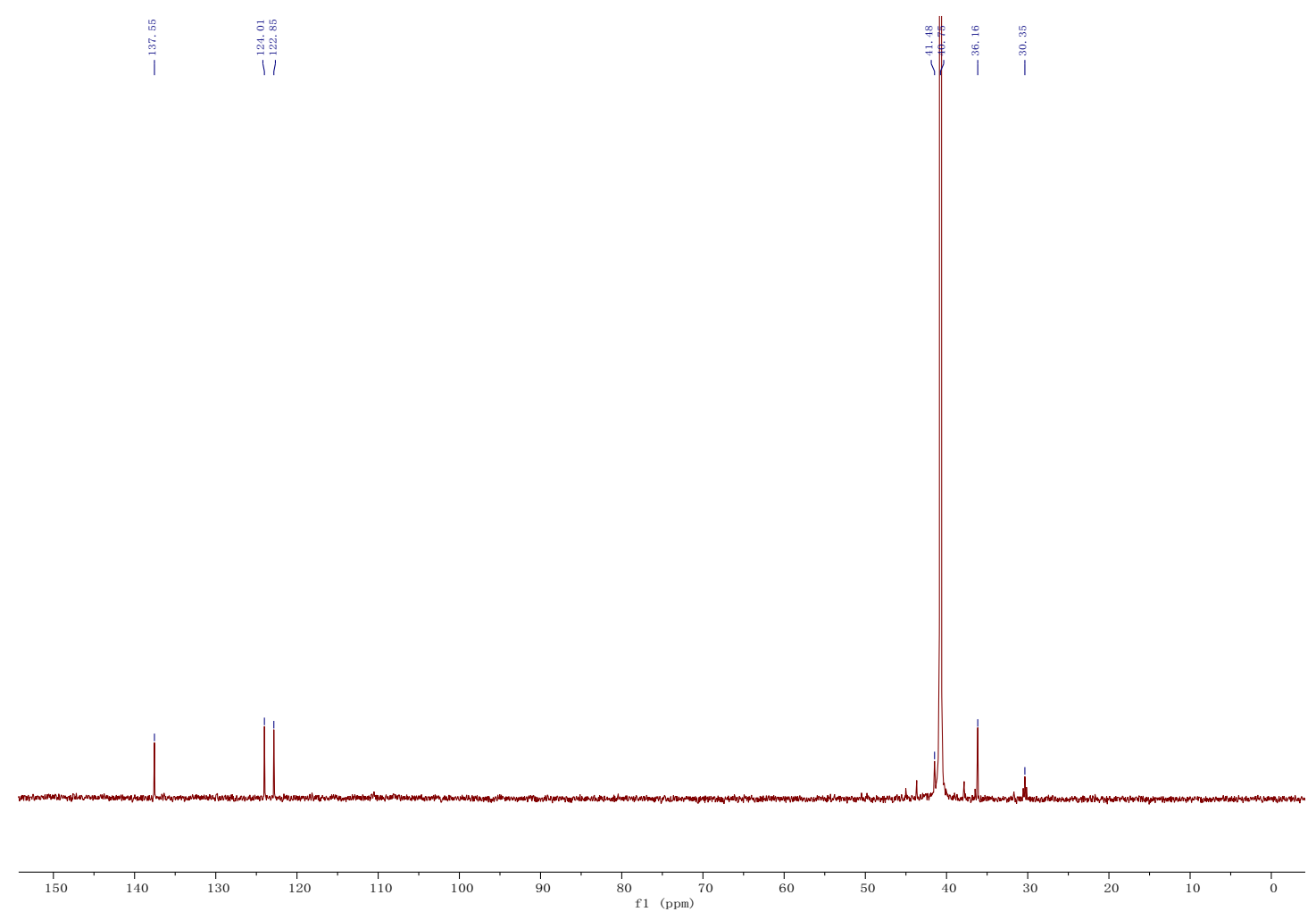

Figure S11. ${ }^{13} \mathrm{C}$ NMR (100 MHz) of MFIM-2 in DMSO.

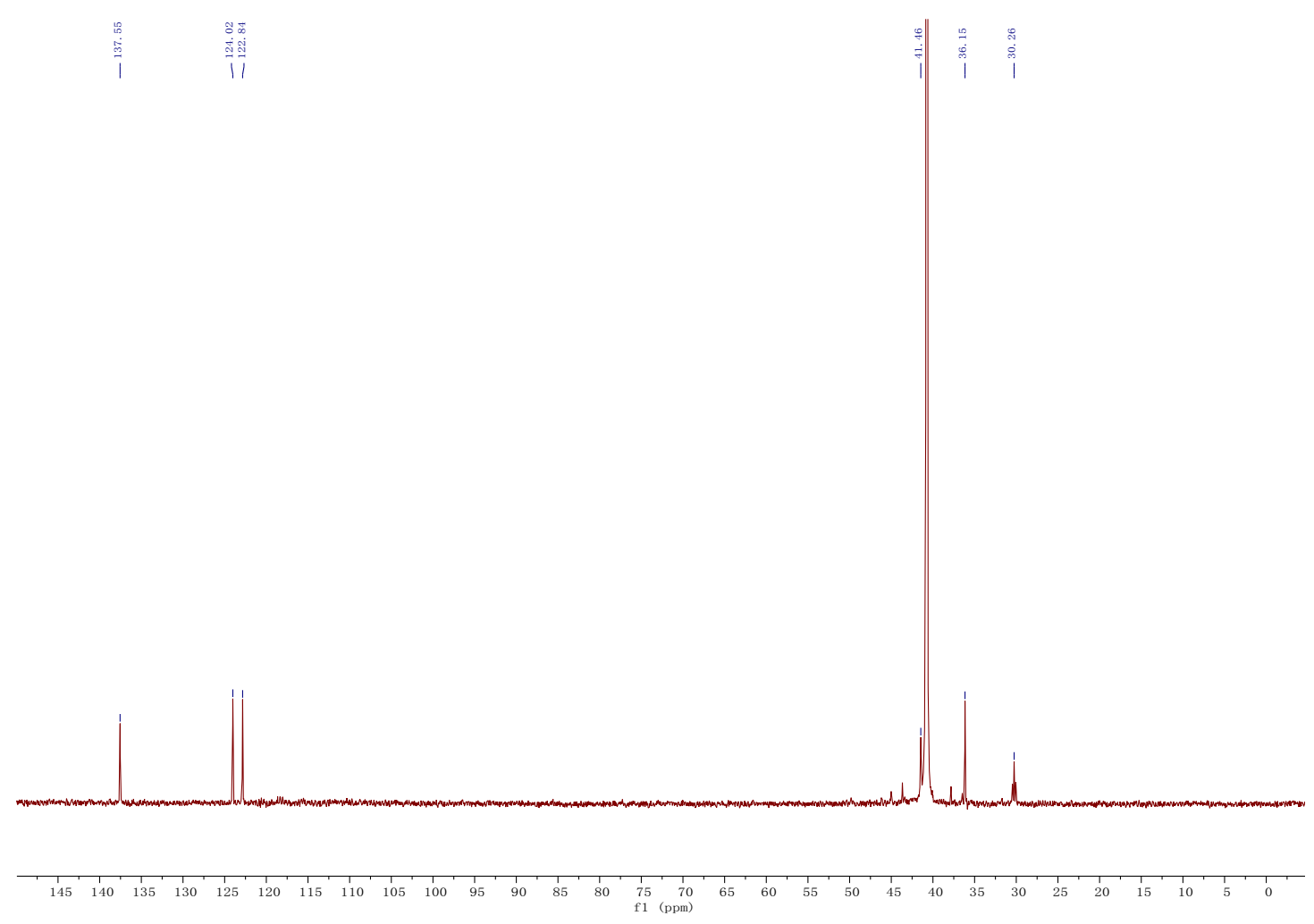


Figure $\mathrm{S} 12 .{ }^{13} \mathrm{C}$ NMR $(100 \mathrm{MHz})$ of MFIM-4 in DMSO.

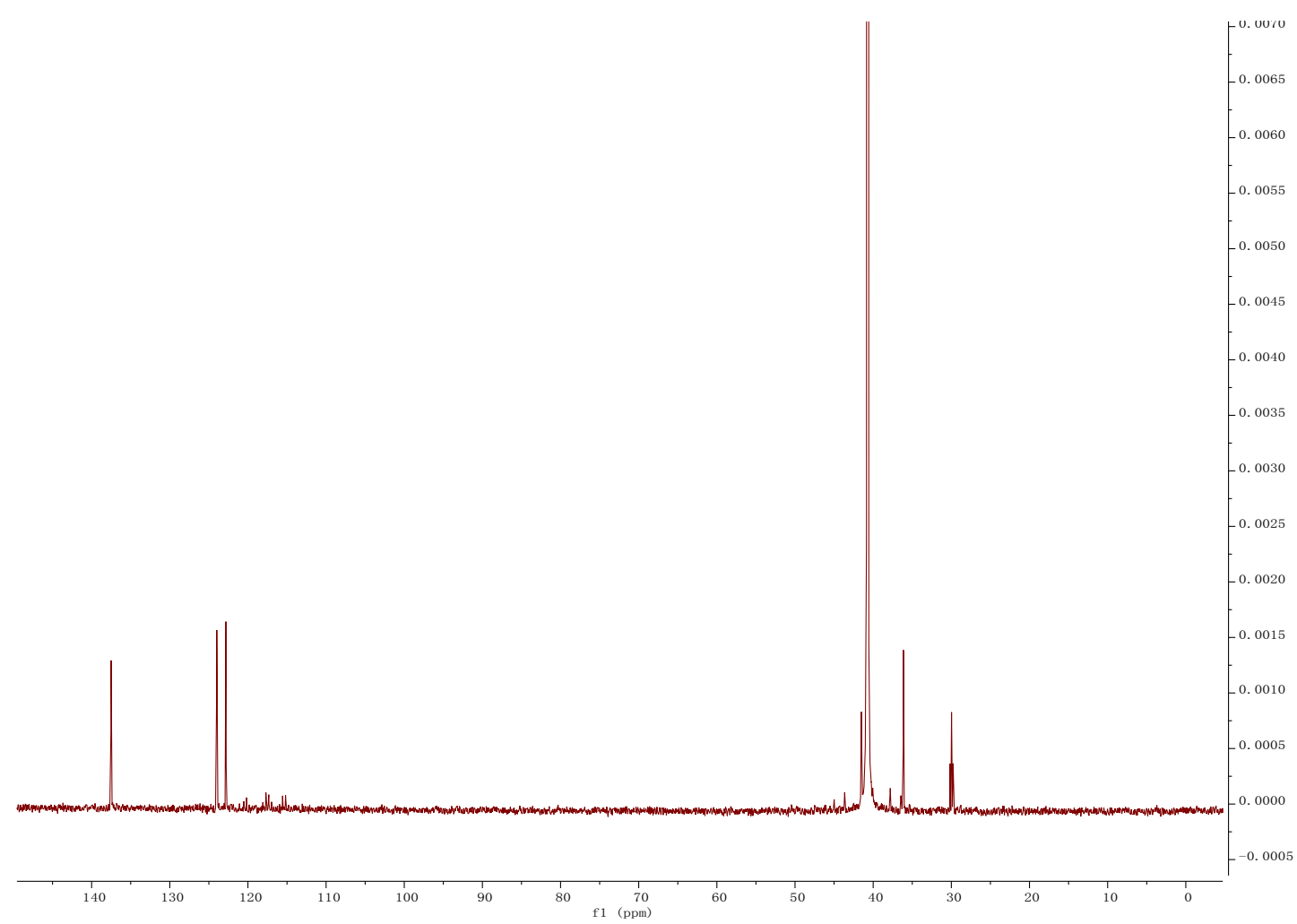

Figure S13. ${ }^{13} \mathrm{C}$ NMR $(100 \mathrm{MHz})$ of MFIM-6 in DMSO.

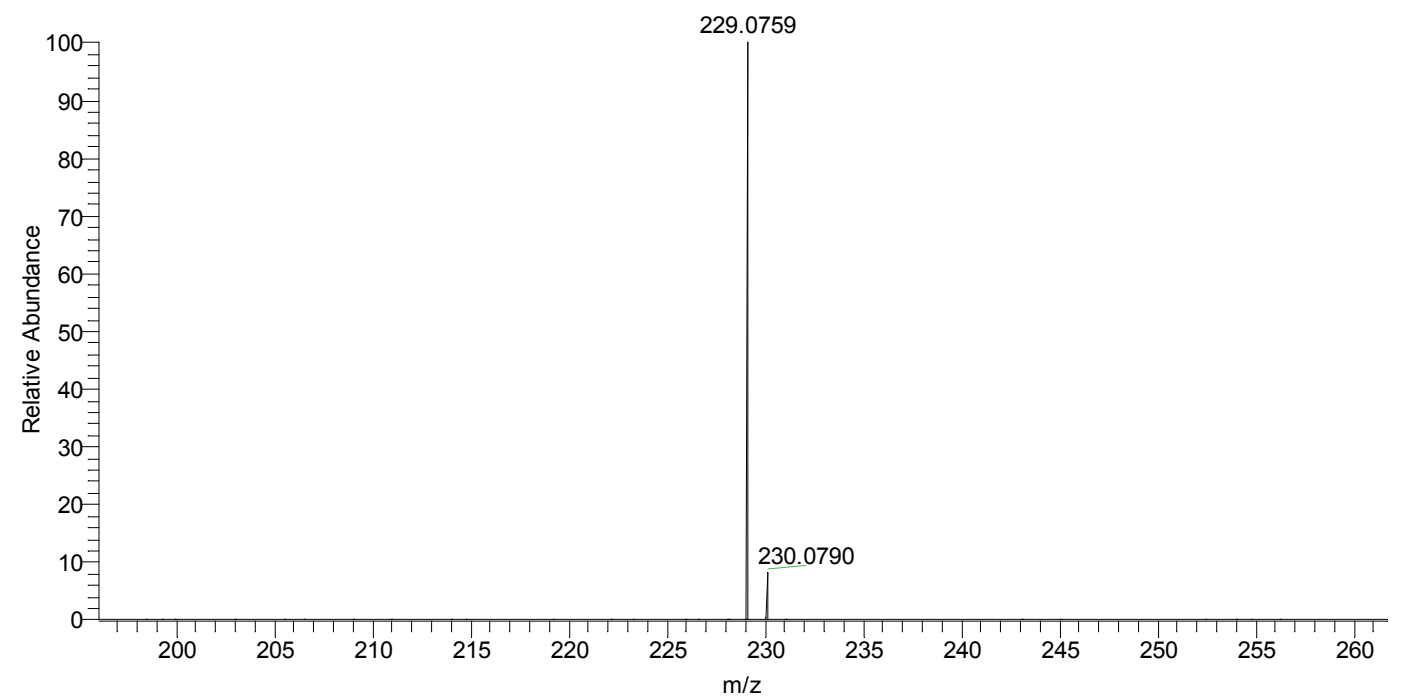

Figure S14. Mass spectrum of MFIM-2. 


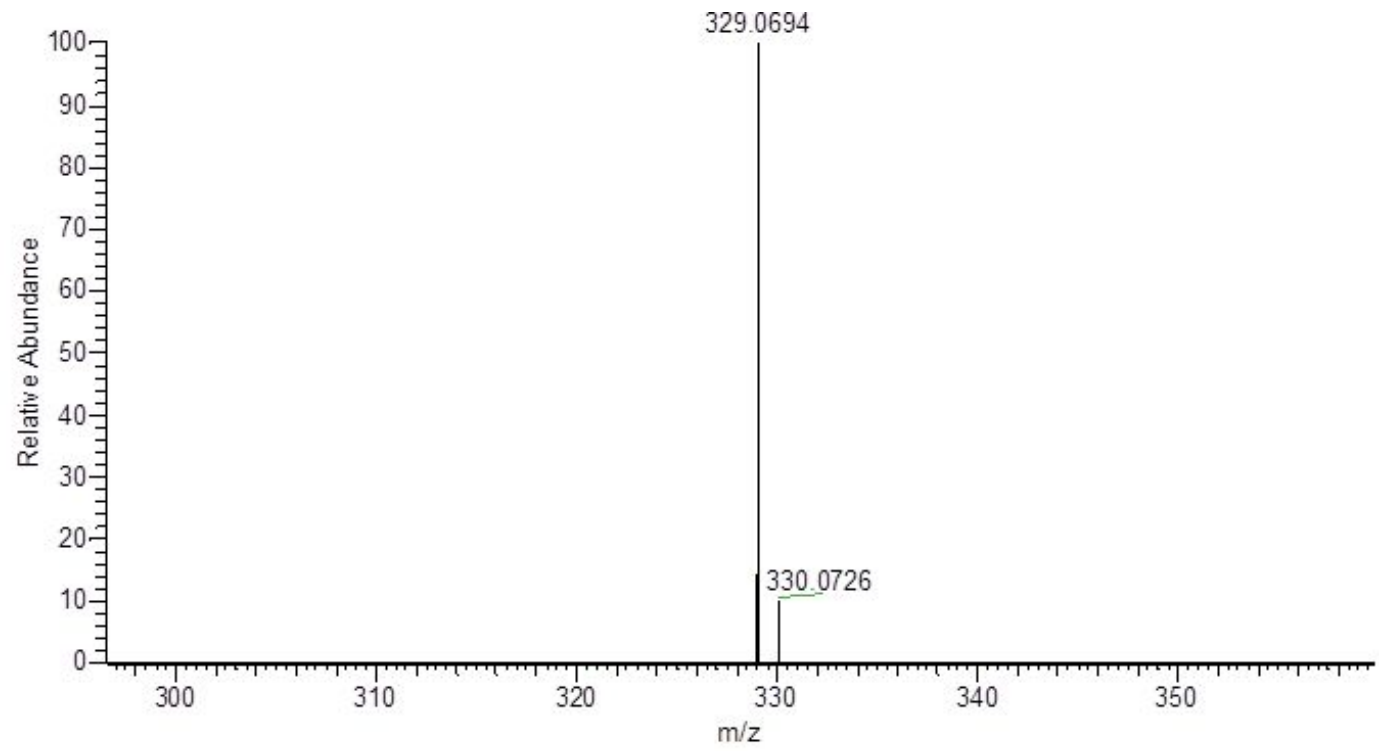

Figure S15. Mass spectrum of MFIM-4. 


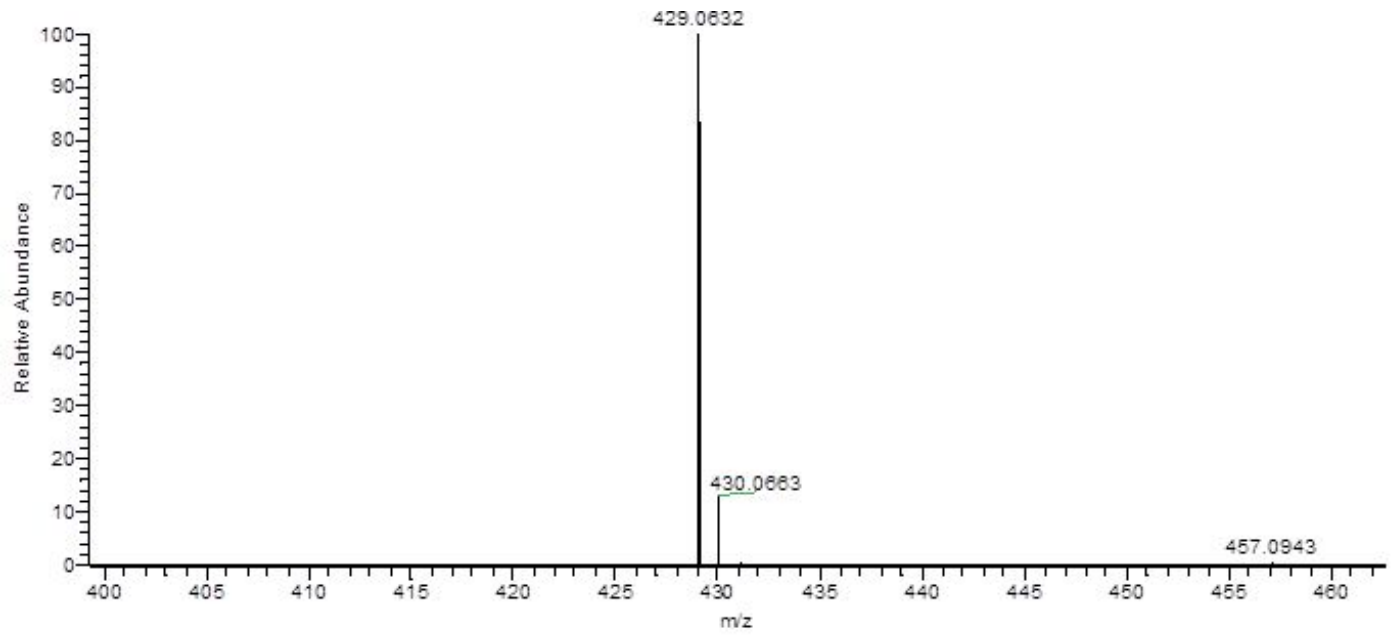

Figure S16. Mass spectrum of MFIM-6. 